\title{
How Is the Perception of Teachers in Indonesia about Portfolio Assessment for Elementary School?
}

\author{
Yogi Prihandoko*, Rochmat Wahab, Insih Wilujeng, Badrun Kartowagiran \\ Department of Primary Education Doctoral Program, Graduate School, Universitas Negeri Yogyakarta, Indonesia
}

Received October 18, 2020; Revised December 2, 2020; Accepted December 17, 2020

\section{Cite This Paper in the following Citation Styles}

(a): [1] Yogi Prihandoko, Rochmat Wahab, Insih Wilujeng, Badrun Kartowagiran, "How Is the Perception of Teachers in Indonesia about Portfolio Assessment for Elementary School?, " Universal Journal of Educational Research, Vol. 8, No. 12B, pp. 8294-8303, 2020. DOI: 10.13189/ujer.2020.082634.

(b): Yogi Prihandoko, Rochmat Wahab, Insih Wilujeng, Badrun Kartowagiran (2020). How Is the Perception of Teachers in Indonesia about Portfolio Assessment for Elementary School?. Universal Journal of Educational Research, 8(12B), 8294-8303. DOI: 10.13189/ujer.2020.082634.

Copyright $\mathrm{C} 2020$ by authors, all rights reserved. Authors agree that this article remains permanently open access under the terms of the Creative Commons Attribution License 4.0 International License

\begin{abstract}
This research is a case study that seeks to reveal teachers' perceptions of portfolio assessment in primary schools in Indonesia. The research sample was 20 elementary school teachers in Central Java Province, Indonesia, representing senior teachers, master teachers, young teachers, and junior teachers. Data collection used depth interviews which were designed based on 10 powerful portfolio assessment principles. Qualitative data analysis was performed using interactive data analysis which included condensation data, display data, and conclusion. The results were showed that 6 of 10 principles of portfolio assessment were approved by the majority of teachers, while others were not. Two principles, namely the effectiveness of time and energy (principle 2) and portfolios as a new learning perspective (principle 8) are rejected by most teachers in Indonesia. The two other principles, namely the importance of teacher cooperation in portfolio assessment (principle 3 ) and the role of portfolio assessment as self-evaluation (principle 9) received low approval scores. The obstacles for the teacher to carry out the portfolio assessment are the problem of the length of time it takes, the large number of elementary school students in a class, and the teacher's low insight into portfolio assessment. Research recommendations are that the success of portfolio assessment will be achieved if it is carried out in a structured and sustainable manner; it is necessary to carry out training and monitoring of teacher performance to maximize assessment, learning and evaluation of learning; and the need to adapt the e-portfolio assessment for primary schools.
\end{abstract}

Keywords Assessment, Portfolio, Elementary School, Teacher

\section{Introduction}

Portfolios are one form of authentic assessment to measure student performance systematically and comprehensively. This is in line with Saputri's [1] opinion which states that the portfolio is one form of authentic assessment that seeks to demonstrate the skills and competencies students have achieved. Portfolio assessment at elementary school level can be substantially done through a collection of meaningful tasks to solve problems that will be faced by students in the future. Characteristics of elementary school students when viewed from the level of cognitive and psychological development tend to like to try new things and have a great curiosity [2]. The theory should be one of the foundations that encourages teachers not to only use learning methods as well as test-based or cognitive-based assessment.

Learning innovations, especially in the aspect of assessment must also be the focus of the development of learning in primary schools [3]. The role of the teacher in accommodating various types of assessments both conventional and contemporary assessments that are being trending cannot be separated from the insights and knowledge possessed by the teacher. In the context of 
portfolio assessment, teachers must understand the definition, development process, topic selection, and weaknesses and strengths of the portfolio [4]. Empirical evidence shows that elementary school teachers have a very shallow understanding of portfolio assessment [5]. This low level of teacher insight is a major factor in the development of portfolio assessment in Indonesia, especially at the elementary school level. The systemic impact of this low level of teacher insight is certainly the lack of use of portfolio assessment or may not even be applied at the elementary school level.

Based on the empirical facts of the results of previous studies, the current level of application of primary school portfolio is still far from being successful. Teachers have difficulty in preparing portfolio assessment rubrics [6]. This becomes an obstacle in portfolio assessment because one important component in portfolio assessment is the rubric of assessment which will later convert scores into student learning outcomes. Furthermore, the results of other studies also indicate that so far portfolio assessments conducted by primary school teachers substantially depend on private worksheet books which, according to some teachers, are the mainstay of teachers in learning today [7]. In addition, another empirical fact was found that in one of the favorite schools that had used portfolio assessment as a form of assessment, it was also not entirely successful. The fact that is found in the field is that the portfolio is only in the form of a container owned by each student but is not equipped with a cover and table of contents, but it is also not done regularly and periodically [8].

Portfolio assessment should be carried out periodically and continuously to continuously monitor the level of competency development achieved by students at any given time unit. The implementation of the assessment which is carried out by solidifying the process and results is one of the main principles of authentic assessment [9]. The portfolio process that is continuously monitored by the teacher will be an objective assessment tool and not solely based on the final results. Portfolios that are carried out periodically are one of the advantages of the portfolio that is increasing student activity and learning outcomes [10]. In addition, several research results have also shown the advantages of the portfolio, namely creating meaningful learning and helping students learn better [11]. In this context, the portfolio also provides the opportunity for teachers to document student growth [12] as one form of moral and academic teacher accountability to students' parents. This will truly be authentic proof when parents ask questions about the progress that their children have achieved during their education in elementary school. Once again, portfolio assessment provides many benefits for teachers. Based on the background description above, this study seeks to uncover the true perceptions of teachers about portfolio assessment at the elementary school level. The results of teacher perception are expected to be a real picture of implementation, success, constraints or obstacles as well as things that are needed by teachers in carrying out portfolio assessment.

\section{Methods}

\subsection{Research Designs and Samples}

This research is a qualitative case study. This study seeks to investigate phenomena in the context of real life regarding the implementation of portfolio assessments at the elementary school level. The research sample was twenty elementary school teachers in Central Java Province, Indonesia. The twenty teachers who were the subjects of the study consisted of 12 women and 8 men. 10 teachers are fifth grade teachers, while 10 teachers are sixth grade teachers. Teachers who are the subject of research are divided into senior teachers who have taught more than 10 years as 5, teachers who have passed master's degree 4, young teachers who teach less than 5 years 4 , and junior teachers who have taught 5-10 years as 7.

\subsection{Data and Instrument Collection}

Data collection techniques are done through in-depth interviews with the type of semi-structured interview. The selection of this technique is intended so that data collection can be done optimally, but not from the focus or research context. Data collection instruments in this study are adapted from 10 powerful principles in the use of portfolios [13]. The 10 powerful principles used as the basis for developing the instruments in this study are explained in table 1. The research questions conducted were 10 main questions, each of which represents 10 principles of portfolio assessment. The process of collecting data through in-depth interviews was carried out on 3 January 2020 to 27 March 2020

\subsection{Research Procedure and Data Analysis}

This research was conducted by collecting data on 20 elementary school teachers representing city schools, village schools, favorite schools, remote schools, and schools of international standard. Researchers conducted in-depth interviews with 20 grade 5 and 6 elementary school teachers. Interviews of teachers were conducted for 1 day using 10 questions created based on 10 portfolio assessment principles. The results of in-depth interviews are recorded and recapitulated using the author's notes in detail and in full. After the interview is finished, the data that have been collected are analyzed qualitatively. Data analysis techniques in this study used the interactive analysis of Miles, Huberman and Saldana [14] which included data condensation, data display, and conclusion. 
The results of data analysis are then presented in the form of holistic descriptions and realistic examples as they become one of the case study's characteristics.

Table 1. 10 powerful portfolio assessment principles

\begin{tabular}{|c|c|}
\hline Principles & $\begin{array}{c}\text { Description } \\
\text { trained }\end{array}$ \\
\hline 1 & Teacher and administrator must plan for and be \\
\hline 2 & Sufficient resources of time and energy \\
\hline 3 & $\begin{array}{c}\text { Teacher must work as a team to plan for the } \\
\text { implementation }\end{array}$ \\
\hline 4 & Parents and the public need to understand \\
\hline 5 & The teacher's role is vital as a facilitator \\
\hline 6 & Documentation of the process and student \\
achievement
\end{tabular}

\section{Result}

Based on in-depth interviews conducted with respondents of twenty elementary school teachers using 10 main questions about portfolios in elementary schools, an interesting fact was obtained as interpreted in Figure 1. The first interview uses principle 1 regarding the training that has been conducted on portfolio assessment. 14 or $70 \%$ of teachers answered that they have never received specific training on portfolio assessment. Meanwhile, 4 $(20 \%)$ master teachers have acquired knowledge of portfolio assessment during their master studies. The other $2(10 \%)$ teachers said learning about portfolios could be self-taught using the internet and books. In the interview in principle 2 about the adequacy of time to use portfolio assessment, 10 teachers $(50 \%)$ answered strongly disagree, because the time used to carry out the portfolio assessment was very long. The energy required, such as costs, is also a lot. So, this is a major obstacle to implementing portfolio assessments in schools. Another 8 teachers $(40 \%)$ also said the same thing. Furthermore, the other $2(10 \%)$ teachers actually said that the downside of the portfolio was that it took a long time, thereby reducing study time for something else.

Furthermore, in the interview in principle 3, the answers given by the teacher varied. Principle 3 is about teamwork with teachers to plan a portfolio assessment. 7 teachers $(35 \%)$ said that cooperation between teachers as a team is very important. 8 teachers $(40 \%)$ said that collaboration between teachers would be troublesome for other teachers if it was done too often. 3 teachers $(15 \%)$ said that cooperation between teachers had no effect. Furthermore, 2 other teachers (10\%) said that cooperation was not necessary. The interview principle 4 is about the importance of the public and parents understanding portfolio assessment. 18 teachers or $90 \%$ of respondents stated that the understanding of parents and the public is very important, 1 teacher or $5 \%$ said that the support of parents and the public has different roles, the most important thing is parents, because apart from monitoring student activities at home, parents can become teachers for their children at home, 1 other teacher $(5 \%)$ said that the understanding of parents and the public did not have a significant effect.

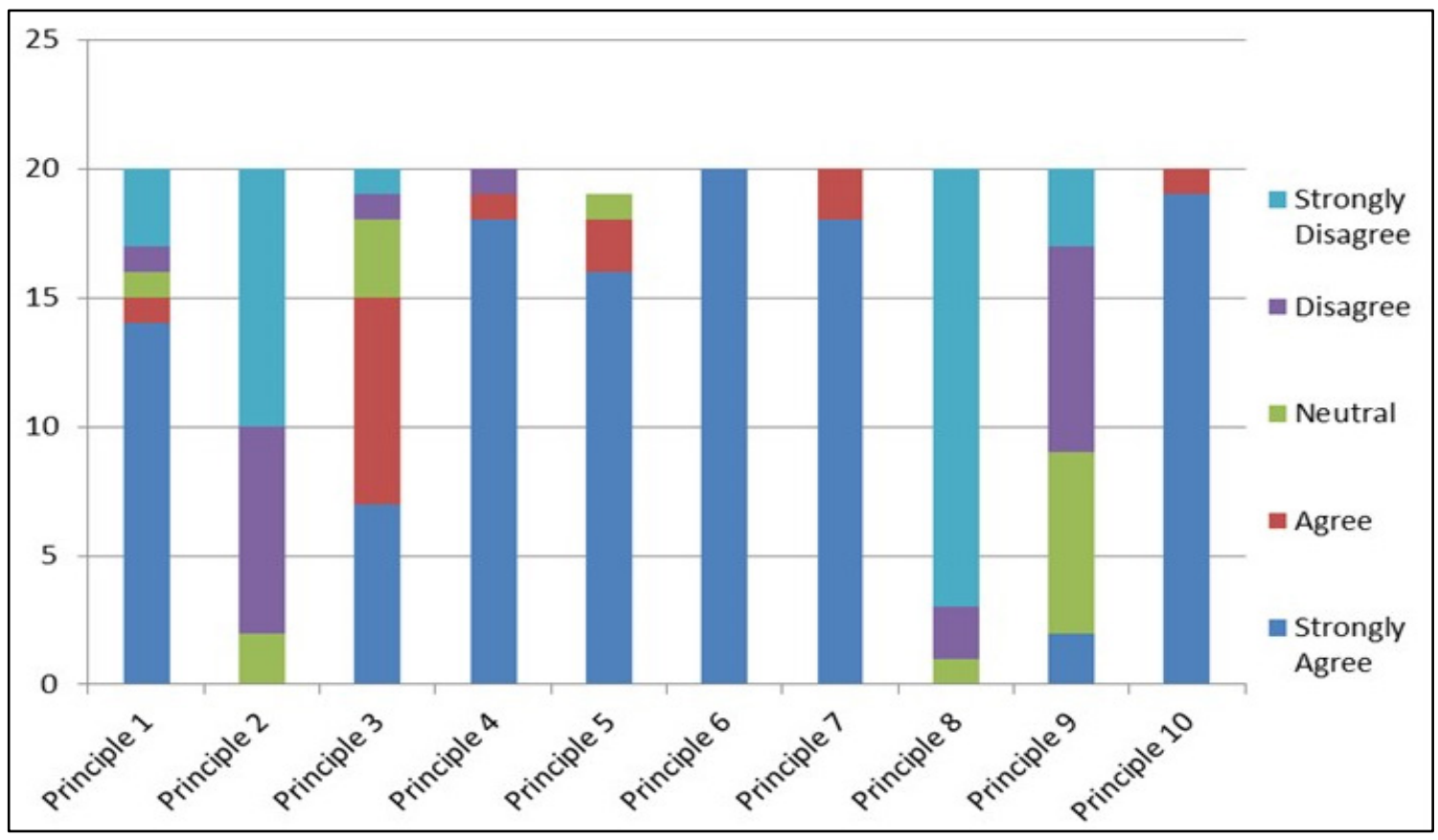

Figure 1. Teachers' perceptions of portfolio assessment in Indonesia 
Interviews on principle 5, regarding the importance of the role of teachers in portfolio assessment in primary schools received approval from 16 teachers $(80 \%) .2$ teachers $(10 \%)$ stated that the role of parents is also important, because portfolio assessment will provide additional assignments for students and take longer. Another teacher (5\%) said that in the portfolio assessment there are several components that cannot be separated. Furthermore, the interview in principle 6 about the role of portfolios in documenting the development process and student achievement received responses from 20 teachers $(100 \%)$ who strongly agreed. Principle 7 regarding the role of portfolio assessment as a form of student development process also received a positive response like the previous principle. 18 teachers $(90 \%)$ strongly agreed with this statement, and 2 other teachers $(10 \%)$ agreed.

In principle 8 regarding portfolios as a new perspective on learning, the majority of teachers give the opposite answer. 17 teachers (85\%) strongly disagreed and 2 teachers $(10 \%)$ considered portfolio assessment not a new perspective on assessment in Indonesia. Another 1 teacher gave a neutral answer to principle 8. In principle 9, 2 teachers $(10 \%)$ said they strongly agreed because seeing each assignment and development at any time would make it easier for students to evaluate their own strengths and weaknesses. 7 teachers were neutral (35\%), 8 teachers $(40 \%)$ actually disagreed, and 3 teachers $(15 \%)$ said they strongly disagreed. In the last principle, principle 10 , which contains the role of portfolio as a tool for collecting, selecting, and reflecting, was approved by the majority of teachers. 19 teachers $(95 \%)$ strongly agreed with this principle, and 1 teacher (5\%) agreed.

\section{Analysis}

Analysis needs to be carried out to discuss the details of each data that have been presented and convey important data obtained by researchers, which have not been covered in the main data presentation. This data are additional information obtained by researchers in the in-depth interview to complement and further broaden the readers' insight. The interview data on principle 1 regarding the training that has been carried out on portfolio assessment illustrate that the training that is often carried out in Indonesia is training on curriculum implementation only [15]. The training has not yet touched on authentic assessment as one of the mandatory assessment methods in the current curriculum. This was also supported by in-depth interviews which illustrated that there was no training on portfolios. All teachers stated that the knowledge they had about portfolio assessment was that they got during college and professional education. Therefore, it is natural that the knowledge of the teacher's portfolio is not optimal.
Principle 2, on the adequacy of time to use portfolio appraisal, illustrates the constraints to portfolio appraisal that consume time and energy. However, it turns out that some teachers still consider the aspects of the benefits of portfolios for students, so even though it requires a lot of time and energy, portfolios still have significant benefits for the development of student competencies [16]. Based on the in-depth interview, the answer is that the actual time spent working on portfolios for students is a good learning time, besides that for teachers, they can also find out students' abilities personally through their portfolio work.

Principle 3, regarding teamwork for teachers to plan a portfolio assessment, shows that there is a heterogeneity of opinions about cooperation among teachers. Different characters, mindsets and backgrounds will bring different types of teaching to each teacher [17]. In principle, all teachers want to build good networks and cooperation between teachers, but special considerations are needed regarding technicalities and the time when joint planning between teachers can be done. It is also necessary to emphasize that all these processes aim to create the best assessment creations in accordance with the characteristics of each student [18]. The teacher response to the interview in principle 4 about the importance of the public and parents understanding portfolio assessment has shown that almost all teachers said that the role of parents and the public is very important. Portfolios as student assignments need support from parents and other parties who may be able to provide motivation and support both material and non-material when students work on portfolio assignments at home [19]. However, there were a small number of teachers who thought they had an important role in this assessment.

Furthermore, in principle 5, the importance of the role of teachers in portfolio assessment in primary schools was also agreed upon by the majority of teachers. The teacher's role is vital, the teacher compiles learning scenarios, assignments, and assessments of student portfolios [20]. The use of portfolio assessment is also entirely the teacher's job, not all teachers are willing to use portfolio assessment. However, the role of parents is also important, because portfolio assessment will provide additional assignments for students and take longer. The role of parents in controlling and monitoring student performance at home is an inseparable part, in addition to the important role of teachers in schools. Teachers, school principals, and parents have an equally important role. Portfolio assessment cannot be carried out when the facilities at the school are not supported and do not get permission from the school principal. However, the principal has an impact on various activities in the school, be it for assessment, learning, or lesson planning [21].

Principle 6 on the role of portfolios documenting student development and achievement processes is the only principle all teachers agree on. All teachers consider 
this an advantage of portfolio assessment over other assessments. Through portfolio assessment, all student assignments will be stored neatly and systematically [22]. Teachers can easily check the weaknesses of students and also what the strengths, talents and interests of students are through analyzing each student's assignment. Furthermore, in principle 7 regarding the role of portfolio assessment as a form of student development process also received approval from the majority of teachers, they realized that portfolios were a powerful tool to determine the level of student development [23]. However, some teachers also argued that a portfolio assessment is more appropriate if it is called a progress note, or student development archive. Principles 7 and 6 are integral. Principle 6 is responsible for documenting each student's work, while principle 7 is the result of the analysis of the document.

In principle 8 regarding portfolios as a new perspective in learning, the majority of teachers reject it. Portfolio assessment has been around for a long time, but currently there is innovation and development to adapt to technology and needs [24]. Some people consider this to be new, it is not completely wrong because there is always something new in an innovation, so that this assessment will still exist into the future. Principle 9 regarding the role of portfolio assessment as self-reflection illustrates that current teacher perceptions of portfolio assessment can be an effort for self-reflection. In fact, all assessments are aimed at student self-evaluation, and the key to self-evaluation is not the assessment, but how the feedback given by the teacher to stimulate students to evaluate themselves [25]. Self-evaluation on portfolio assessment in primary schools cannot be carried out through portfolios, primary school students need a strong teacher role and peer assessment or personal assessment is deemed more appropriate. A small proportion of teachers also think that portfolios are a form of self-development documentation, not a form of reflection. Self-reflection will occur when an analysis of each task is carried out at a certain time. It takes a long time, especially if the number of students is large.

In the last principle, principle 10, which contains the role of the portfolio as a tool for collecting, selecting, and reflecting, was agreed upon by almost all teachers. The majority of teachers have the same perception, they assume that the portfolio is a collection of all student assignments, then assesses, and the results of the assessment are a form of long reflection. All these stages describe a complex and systematic process sequence [26]. The reflection that appears is a description of the students' abilities during a certain time, for example 1 semester. The teacher can know what to do in the next semester. However, there is one important note from one of the teachers, this note is that not many teachers have used this as a classroom assessment. Teachers prefer to use tests, because they are considered practical, easy to analyze, and fast when compared to portfolio assessments.

\section{Discussion}

Teachers' perceptions about portfolio assessment in primary schools as depicted in the descriptive narrative of the research results provide a clear picture that portfolio assessment has not been successfully implemented in primary schools. The application of portfolios in schools which are the subject of research has indeed been carried out although with very minimal frequency. However, the obstacles faced by teachers, such as the length of the portfolio assessment process, appear to be a major factor in the unsuccessful implementation of portfolio assessment in primary schools. The implementation of portfolio assessments that has not been carried out regularly and regularly is a very common problem in its implementation [27]. The length of time constraints in portfolio assessment is also influenced by the number of primary school students in each class over 25 students, while the portfolio must facilitate each student personally to communicate and consult with the teacher [28].

Through further research conducted by researchers, teachers' knowledge of portfolios is also suspected to be a limiting factor. Low insight into portfolio assessment certainly limits the creativity of teachers to innovate in portfolio assessment that is not limited to certain subjects. Based on the results of interviews, teachers in schools still have the perception that portfolios are work assignments that must be displayed and if they are seen as having aesthetic values and giving pride to the students who make them. Portfolios are only often heard by them, but substantially cannot be mastered well [29]. The lack of teacher insight is indeed one of the systemic impacts that is motivated by the lack of training or workshops that have been attended or conducted by teachers in elementary schools. Based on the teacher's admission, they gain knowledge about portfolios during their formal education as well as in teacher professional education. It also shows that stakeholders and agencies need attention to provide facilities that support the development of portfolio assessment as one of the authentic assessment methods in primary schools [30].

Portfolios as a form of authentic assessment are one of the assessment methods in the curriculum in Indonesia today, and their advantages and benefits are undoubtedly. The benefits of portfolio assessment are an important basis in carrying out portfolio assessments in primary schools. Therefore, this study also explores teachers' perceptions of the benefits of portfolio assessment. In general, based on the research results, the teacher's knowledge of the benefits of portfolios as a form of track record of progress in competency development is regularly taken by students when participating in learning activities. This illustrates that teachers' insights about the 
benefits of portfolio assessment have not been fully formed. Portfolio assessment actually has many benefits that teachers in primary schools have yet to reveal. First, portfolio assessments provide personal feedback for students. This is a stimulus so that students can do self-evaluation [11]. The feedback given by the teacher to students can provide an overview of the extent to which the abilities they have and what can be planned to achieve the targeted learning outcomes [31].

Self-evaluation for students is very important for the psychological and mental development of children. Self-assessment is able to change the habits of students who are initially lazy and indifferent to their competencies to become active and more independent [32]. Students who have carried out self-assessments can be shown the ability to motivate, generate thoughts, strategies and behave to achieve what they do not have or accomplish what they lack. In the context of portfolio assessment, this is very important because students not only receive grades from the teacher raw, but also carry out self-assessment of parts or skills they have not mastered. This is a positive value for the portfolio when compared to the test assessment that makes students resign themselves to receiving marks for what students have done.

Second, portfolios provide benefits for students to improve learning outcomes and social interaction [33] when the teacher assigns portfolio assignments to be done in groups. The results showed that the portfolio assessment succeeded in improving learning outcomes, when compared with students who were not given a portfolio [8]. With regard to student social interactions, portfolio assessment has provided meaningful assessment and increased student collaboration and learning activities. When viewed from the aspect of child psychological development, elementary school students are indeed at the stage of searching for identity and need a means of transformation.

Second, portfolios provide benefits for students to improve learning outcomes and social interaction [4] when the teacher provides portfolio assignments that must be done in groups. The results showed that portfolio assessment succeeded in improving learning outcomes, when compared with students who were not given a portfolio [34]. With regard to student social interactions, portfolio assessment has provided meaningful assessment and increased student collaboration and learning activities. When viewed from the aspect of child psychological development, elementary school students are indeed at the stage of searching for identity and need a means to transform changes from childhood to adolescence. Establishing social relationships and interactions with peers is one of the positive aspects to stimulate a good social life, care, and personality. This is in line with one of the portfolios' missions which in this context is expected to be a medium for building a positive self-image through a pattern of cooperation between people [35]. The benefits of this portfolio are one of the benefits that are rarely known by teachers. However, it should also be noted that this is a companion impact in shaping student character, in addition to improving learning outcomes which are the main objectives.

Third, portfolios provide benefits to prevent and overcome student learning failures which are caused by self-development factors and the learning atmosphere [36]. As is generally known by teachers, portfolios provide information about the development of student competencies, however, the teacher does not know that this is actually a means to overcome student learning failures. The diversity of abilities possessed by each individual with different backgrounds will certainly be a problem if treatment or learning is done classically [37]. Portfolios are one of the solutions to overcome potential learning failures by personally early detection of students who experience symptoms or learning barriers. In addition, portfolio assessment is also considered fair for students because it does not only evaluate learning outcomes, but also the assessment process in a transparent manner [38].

This benefit illustrates to teachers that a reliable assessment is not only obtained from tests. Often students experience mental disorders due to failure in the test, students become psychologically depressed. Remedies are not the solution to this problem. The teacher's role in this can be done by not only focusing on assessing results. Teachers must adopt an assessment process which in addition to being a reference for assessment, is also a means of detecting student failures from an early age. However, elementary school teachers rarely use this use. So once again it needs to be said that how important it is to master the theory and basic concepts of assessment for a teacher. The role of teachers at the primary school level cannot be denied as the main actors in planning, implementing, and evaluating learning [39]. This is a characteristic of learning in elementary schools when compared to secondary schools, where students have reached adulthood so that the dominant role of the teacher begins to decrease because the level of student maturity also has an impact on their responsibility in learning.

Fourth, the benefits of portfolio assessment for teachers other than those mentioned above are increasing creativity and reflecting media on learning that have been done. The implementation of a substantial portfolio assessment is certainly not only a burdensome task for students, but further portfolio assessment is expected to be a meaningful task, in accordance with the context, where students can apply the theory they have acquired in a new skill and skill [40]. This of course requires teachers to be creative and innovative in designing portfolio assignments that are relevant to the material and learning objectives, as well as their uses [36]. Therefore, it will indirectly stimulate teachers to find out, look for references for portfolio assessment and develop creativity.

Portfolios as an intense communication medium 
between students and teachers certainly provide feedback to teachers about the learning process that has been carried out. It is hoped that this can become a medium for self-reflection of teachers in carrying out learning and assessment. Given the diversity of student characteristics that exist in each individual, the application of theory and research results sometimes cannot be used as standard references, and the key is of course self-reflection based on what has been done as a medium for preparing future portfolios [33]. This is one of the advantages and benefits of portfolio valuation that may not be obtained in other valuation methods.

Starting from the results of research on perceptions, knowledge and benefits of portfolios, naturally it refers to the solutions and recommendations obtained based on a critical analysis of the empirical facts of the research results. Some of the recommendations that can be produced in this study are as follows. First, the success of the portfolio assessment program will only be achieved if it is carried out in a planned and sustainable manner. A planned and structured portfolio is an absolute prerequisite for achieving maximum assessment objectives. The portfolio assessment process is not only about how to assign assignments to students, but the role of the teacher in guiding and determining aspects of the assessment in a structured manner. The difficulty of teachers in general is in the implementation stage of the assessment with unclear criteria, or even the value of 'compassion' is still real because of human nature.

Assessment rubrics that are in accordance with the basic competencies of subjects do require the teacher's thinking and creativity. This is often an obstacle for teachers in assessing student portfolio work results [41]. A portfolio assessment that is carried out continuously will certainly provide a systematic and periodic track record of student development [12]. This actually also makes it easy for teachers as an effort of moral and academic accountability to parents of students. In today's era, of course, many parents are concerned and critical of the development of their children who are currently studying at the school concerned, portfolios certainly provide authentic evidence of the development of competency attainments that students have achieved.

Second, the lack of teachers' knowledge about portfolio assessment requires handling from related agencies. One of the obstacles in the implementation of portfolio assessment stemming from the lack of insight of teachers is one of the systemic impacts caused by the government's lack of attention in conducting portfolio assessment training. This is one of the important findings in this study. In addition, education stakeholders both at the central and regional levels, especially school principals, also need to monitor teacher performance [42]. Monitoring means learning planning, compiling learning tools, and evaluating learning which is carried out periodically and periodically. This monitoring is expected to maintain teacher professionalism, especially in the context of assessment.

Teachers should not use one of the dominant assessments, but are expected to adapt various assessment models. The use of various forms of assessment is expected to increase motivation and learning outcomes, as well as to maximize the development of psychological aspects [7]. For example, students who are only evaluated using a type of test, of course the orientation of developing their thinking patterns only refines the theoretical aspects and does not develop their skills. Students tend to accept the dogma that learning outcomes are high test scores. This is a concept of thought that needs to be avoided by teachers, especially at the elementary school level, which is psychologically the most critical stage in the formation of thought patterns and personality [2].

Furthermore, the last or third recommendation in this study is to try to develop an e-portfolio for elementary schools. The development of increasingly advanced technology cannot be avoided by anyone, including children. Every human being, including elementary school children, has begun to depend on things that cannot be separated from technology. It is time for the use of e-portfolios to be reviewed so that they can be adjusted according to elementary level learning. E-portfolio as a portfolio assessment for primary school level is expected to be an innovation and convenience in the process of storing and accessing documents, therefore it is highly recommended for learning in schools [43]. Teachers, students, and also parents can easily view student work and monitor student progress regularly without having to search for documents at school. This is based on the mindset that educational success is not only achieved by teachers and students, but those closest to students who always provide support [44]. It cannot be denied that at the primary school level, the most influential and closest students are parents.

The transition from paper-based portfolios to paperless or e-portfolios has a positive impact on elementary school students, especially in aspects of understanding, critical thinking skills, and meaningful learning [45]. In addition, the practice of e-portfolio assessment can also arouse students' interest in working because elementary students certainly like the use of digital technology. In the early stages, students certainly did not directly access the internet freely. The results showed that at an early stage, elementary school students should be introduced to Microsoft office power points before accessing the internet network [46]. The use of e-portfolios is also expected to introduce students to technology and its use. Students will be familiar and accustomed to using computers, laptops, and so on. However, the use of e-portfolios must also start with good coordination and collaboration between schools and parents. It is undeniable that besides having a positive impact, 
technology is also prone to distortion and it is not impossible for students to be satisfied with other things that exist in digital technology. Therefore, the role of parents in assisting students in using e-portfolios is needed.

\section{Conclusions}

Perceptions of primary school teachers in Indonesia about portfolio assessment vary, making generalizations difficult to make. Teacher backgrounds and research respondents strongly influence this. However, in general, it can be seen that 6 out of 10 portfolio assessment principles are approved by the majority of teachers, while others are not. Two principles, namely the effectiveness of time and energy (principle 2) and portfolios as a new learning perspective (principle 8) are rejected by most teachers in Indonesia. There are 2 other principles, namely the importance of teacher cooperation in portfolio assessment (principle 3) and the role of portfolio assessment as self-evaluation (principle 9) which scores very low.

Barriers to portfolio assessment according to teacher perceptions include the problem of the length of time it takes, the high number of elementary school students in 1 class, and the lack of teacher insight into portfolio assessment. However, basically portfolios have several benefits that are generally not understood by teachers. Some of these benefits include providing personal feedback to students; improve learning outcomes and social interactions; prevent and overcome student learning failures; and increase creativity and learning reflection media. The research recommendations are first, the success of portfolio assessment will be achieved if it is carried out in a structured and sustainable manner. Second, it is necessary to carry out training and monitoring of teacher performance to maximize assessment, learning, and evaluation of learning. Fourth, the need for e-portfolio adaptation for primary schools.

\section{REFERENCES}

[1] R. Dwi, L. Saputri. "The authentic assessment to measure students' English productive skills based on 2013 Curriculum," Indonesian Journal of Applied Linguistics, vol. 7, no. 9, pp. 1-25, 2017. DOI: 10.17509/ijal.v7i2.8128.

[2] T. Lickona, "Character Matters: How to Help Our Children Develop Good Judgment, Integrity, and Other Essential Virtues", Bantam Books, 2004, pp.1-336.

[3] S. Zahra, H. Y. Tandi, "Pengaruh Model Pembelajaran Berbasis Portofolio Terhadap Hasil Belajar Siswa Kelas V Pada Mata Pelajaran IPA SDN No 3 Parigi”, Elementary School of Education E-Journal, vol. 1, no. 3, pp. 1-15, 2016, http://jurnal.untad.ac.id/jurnal/index.php/ESE
[4] O. Birgin, A. Baki, "The Use of Portfolio to Assess Student's Performance," Turkish Science Education, vol. 4, no. 2, pp. 75-90, 2007, http://tused.org/index.php/tused/arti cle/view/673

[5] A. Canga Alonso, "Students' Beliefs on Portfolio Assessment," Revista Alicantina de Estudios Ingleses, vol. 26, no.7, pp. 225-238, 2014, DOI: 10.14198/raei.2013.26.16

[6] J. Jones, "Portfolios as 'learning companions' for children and a means to support and assess language learning in the primary school," Education 3-13, vol. 40, no. 4, pp. 401-416, 2012, DOI: $10.1080 / 03004279.2012 .691374$

[7] E. Kuntarto, R. Gustina, "Pelaksanaan Penilaian Portofolio di Sekolah Dasar," Jurnal Gentala Pendidikan Dasar, vol. 4, no. 2, pp. 190-200, 2019, DOI: https://doi.org/10.22437/gen tala.v4i2.8437

[8] Y. Gulbahar, H. Tinmaz, "Implementing Project-Based Learning And E-Portfolio Assessment In an Undergraduate Course," Journal of Research on Technology in Education, vol. 38, no. 3, pp. 309-327, 2006, DOI: $10.1080 / 15391523.2006 .10782462$.

[9] E. Moria, Refnaldi, M. Zaim, "Using Authentic Assessment to Better Facilitate Teaching and Learning: The Case for Students' Writing Assessment," Advances in Social Science, Education and Humanities Research (ASSEHR), vol. 148, no. 1, pp. 333-337 2018, DOI: 10.2991/icla-17.2018.57.

[10] E. Gregori-Giralt, J. L. Menéndez-Varela, "Validity of the learning portfolio: analysis of a portfolio proposal for the university", Instr Sci, vol. 43, no. 12, pp. 1-17, 2015, DOI: https://doi.org/10.1007/s11251-014-9327-4

[11] M. Çakan, G. Mihladiz, B. G. Taşkin, "How Portfolio Use Affects Students ' Learning and Their Attitudes toward 6th Grade Science Lesson," International Online Journal of Educational Sciences, vol. 2, no. 2, pp. 362-377, 2010, http://www.iojes.net/userfiles/article/iojes_268.pdf

[12] C. Kaur, S. Singh, A.A Samad, H. Hussin, T. Sulaiman, "Developing a Portfolio Assessment Model for the Teaching and Learning of English in Malaysian L2 Classroom," vol. 8, no. 7, pp. 164-173, 2015, https://doi.org/10.5539/elt.v8n $7 \mathrm{p} 164$

[13] S. L. Bryant, A.A. Timmins, "Portfolio Assessment: Instructional Guide: Second Edition to Enhance Student Learning," Hong Kong Institute of Education, 2002, pp. $1-89$

[14] M. B. Miles, A. M. Huberman, J. Saldana, "Qualitative Data Analysis: A Methods Sourcebook", Third Edition, SAGE Publication Inc, 2014, pp. 1-341

[15] Z. Misbah, J. Gulikers, S. Dharma, M. Mulder, "Evaluating competence-based vocational education in Indonesia," Journal of Vocational Education \& Training, vol. 72, no. 4, pp. $488-515$, 2020, DOI: $10.1080 / 13636820.2019 .1635634$

[16] A. Oudkerk Pool, A.D.C. Jaarsma, E.W. Driessen, "Student perspectives on competency-based portfolios: Does a portfolio reflect their competence development?.", Perspect Med Educ, vol. 9, pp. 166-172, 2020, DOI: https://doi.org/10.1007/s40037-020-00571-7

[17] I. Rissanen, E. Kuusisto, M. Tuominen, K. Tirri, "In search of a growth mindset pedagogy: A case study of one teacher's classroom practices in a Finnish elementary school," 
Teaching and Teacher Education, vol. 77, pp.204-213, 2019, DOI: https://doi.org/10.1016/j.tate.2018.10.002.

[18] C. Bovill, "Co-creation in learning and teaching: the case for a whole-class approach in higher education," High Educ, vol. 79, pp. 1023-1037, 2020, DOI: https://doi.org/10.1007/s10 734-019-00453-w

[19] J. Davis, "The effect of using portfolios on student-parent and parent-teacher communication," Proceedings of the Eighth Annual College of Education \& GSN Research Conference, pp. 27-32, 2019, Miami: Florida International University, http://coeweb.fiu.edu/research_conference

[20] S. Odabasi, "The effect of portfolios on students' learning: Student teachers' views," European Journal of Teacher Education, vol. 34, no. 7, 2011, pp. 161-176, DOI: https://doi.org/10.1080/02619768.2011.552183

[21] V. Chikoko, I. Naicker, S. Mthiyane, "Leadership development: School principals' portfolios as an instrument for change," Education As Change, vol. 15, pp. 317-329, 2011, DOI: https://doi.org/10.1080/16823206.2011.619070

[22] P. Mak, K. Wong, "Self-regulation through portfolio assessment in writing classrooms," English Language Teaching, vol. 70, pp. 49-61, 2018, DOI: https://doi.org/10.1093/elt/ccx012.

[23] K.M. Habeeb, A.H. Ebrahim, "Impact of e-portfolios on teacher assessment and student performance on learning science concepts in kindergarten", Educ Inf Technol, vol. 24, pp. 1661-1679, 2019, DOI: https://doi.org/10.1007/s10639018-9846-8

[24] R.P.J. Rajapathirana, Y. Hui, "Relationship between innovation capability, innovation type, and firm performance," Journal of Innovation \& Knowledge, vol 3, no. 1, 2018, pp. 44-55, DOI: https://doi.org/10.1016/j.jik.20 17.06.002.

[25] B.T. Agricola, F. J. Prins, D. M. A. Sluijsmans, "Impact of feedback request forms and verbal feedback on higher education students' feedback perception, self-efficacy, and motivation," Assessment in Education: Principles, Policy \& Practice, vol. 27, no. 1, pp. 6-25, 2020, DOI: 10.1080/0969594X.2019.1688764

[26] T. Williams, H. Vo, K. Samset, A. Edkins, "The front-end of projects: a systematic literature review and structuring," Production Planning \& Control, vol. 30, no. 14, pp. 1137-1169, 2019, DOI: 10.1080/09537287.2019.1594429

[27] T. Sulistyo, "Portfolio assessment: Learning outcomes and students' attitudes," Studies in English Language and Education, vol. 7, no. 1, pp. 141-153, 2020, DOI: https://doi.org/10.24815/siele.v7i1.15169.

[28] R. Lam, "Writing portfolio assessment in practice: individual, institutional, and systemic issues," Pedagogies: An International Journal, vol. 15, no. 3, pp. 169-182, 2020, DOI: $10.1080 / 1554480 X .2019 .1696197$

[29] A. Daud, "Challenges of Using Portfolio Assessment as an Alternative Assessment Method for Teaching English in Indonesian Schools," International Journal of Educational Best Practices, vol. 1, no. 2, pp. 10-114. DOI: https://doi.org/10.31258/ijebp

[30] P.A. Tyas, "Promoting Students' Autonomous Learning
Using Portfolio Assessment in EFL Writing Class," Journal of English Educators Society JEES, vol. 5, no. 1, pp. 75-81, 2020, DOI: https://doi.org/10.21070/jees.v5i1.379

[31] H. Raveloarinirina, A. Barori, "An assessment of students' portfolio of writing in the English language subject," LingTera, vol. 4, no. 1, pp. 59-70, 2017, DOI: https://doi.org/10.21831/lt.v4i1.13586.

[32] M. Sepasdar, H. Esmaeeli, Z. Sherafat, "Is Portfolio Assessment Effective in Improving Iranian EFL Students' Writing?", International Journal of Education and Literacy Studies, vol. 2, no. 4, pp. 1-4, 2014, http://www.journals.aia c.org.au/index.php/IJELS/article/view/1276

[33] B. K. Hermasari, G.R. Rahayu, M. Claramita, "How does portfolio assess interprofessional learning of medical and midwifery students in community-based maternal and children health care," International Journal of Evaluation and Research in Education (IJERE), vol 8, no. 3, pp. 392-400, 2019, DOI: http://doi.org/10.11591/ijere.v8i3.20245

[34] H.C. Dayal, B. Cowie, "Professional Learning Interventionn in Mathematics: A Case of Developing Portfolio Assessment", Australian Journal of Teacher Education, vol. 44, no. 2, pp. $99-118,2019$, DOI: http://dx.doi.org/10.1422 1/ajte. $2018 \mathrm{v} 44 \mathrm{n} 2.7$

[35] P. Roberts, "Bridging East and West-Or, a Bridge Too Far? Paulo Freire and the Tao Te Ching. Educational Philosophy and Theory," vol. 44, no. 9, pp. 942-958, 2012, DOI: https://doi.org/10.1111/j.1469-5812.2011.00797.x

[36] E. Güven, "Effect of the portfolio on the students' removal of failure causes", Procedia - Social and Behavioral Sciences, vol. 116, no. 1992, pp. 3886-3890, 2014, DOI: https://doi.org/10.1016/j.sbspro.2014.01.860

[37] Y. Delgoshaei, M. Talkhabi, "The impact of portfolio evaluation method on the development of children' $\mathrm{s}$ reading skills," vol. 32 , no. 1 , pp. 356-360, 2012, DOI: https://doi.org/10.1016/j.sbspro.2012.01.053

[38] A. Wijayanti, M. Basyar, "The development of thematic integrated e-portfolio media web blog based to increase the scientific literacy of elementary teacher education programs student," Jurnal Pendidikan IPA Indonesia, vol. 5, no. 2, pp. 284-290, 2016, DOI: https://doi.org/10.15294/jpii.v5i2.7684

[39] I. Suarsana, N.P. Supawidhiasih, N. Parwati, “The Use Of Portfolio Assessment To Overcome The Weakness Of Scientific Approach,” JPI (Jurnal Pendidikan Indonesia), vol. 7, no. 1, pp. 41-50, 2018, DOI: http://dx.doi.org/10.23887/j pi-undiksha.v7i1.10394

[40] B. Ghoorchaei, M. Tavakoli, "Self-assessment of Writing in a Portfolio Program: A Case of Iranian EFL Learners," Iranian Journal of English for Academic Purposes, vol. 8, no. 2, pp. 66-79, 2019, http://journalscmu.sinaweb.net/article_9 1741.html

[41] M. Taufik, B.Y.Cahyono, "Developing EFL Students' Writing Skill Through Self-Assessment Integrated With E-Portfolio," IJEE (Indonesian Journal of English Education), vol. 6, no. 2, pp. 171-186, DOI: http://dx.doi.org/10.15408/ijee.v6i2.12019

[42] T. Haldane, "Portfolios as a method of assessment in medical education," Gastroenterology and hepatology from bed to bench, vol. 7, no. 2, pp. 89-93, 2014, 
https://www.ncbi.nlm.nih.gov/pmc/articles/PMC4017561/

[43] M. Maher, P. Gerbic, "E-portfolios as a Pedagogical Device in Primary Teacher Education, : the AUT University Experience," Australian Journal of Teacher Education, vol. 34, no. 5, pp., 2009 DOI: http://dx.doi.org/10.14221/ajte.20 $09 \mathrm{v} 34 \mathrm{n} 5.4$

[44] S. Fatimah, U. Mahmudah, "Data Envelopment Analysis (Dea): Pengukuran Efisiensi Kinerja Sekolah Dasar," Cakrawala Pendidikan, vol. 36, no. 2, pp. 1-16, 2017, DOI: https://doi.org/10.21831/cp.v36i2.11511
[45] S. Karami, F. Sadighi, M. S. Bagheri, M. J. Riasati, “The potential impact of the application of electronic portfolio on Iranian EFL learners' writing performance seeking their gender role," Cogent Social Sciences, vol. 4, no. 1, pp.1-27, 2018, DOI: https://doi.org/10.1080/23311886.2018.156250 9

[46] W. E. Contreras-Higuera, F. Martínez-Olmo, M. J. Rubio-Hurtado, R. Vilà-Baños, "University Students' Perceptions of E-Portfolios and Rubrics as Combined Assessment Tools in Education Courses," Journal of Educational Computing Research, vol. 54, no. 1, pp. 85-107, 2016, DOI: https://doi.org/10.1177/0735633115612784 